FARKASNÉ KURUCZ Zsuzsanna - LÓRÁND Balázs -

- BALOGH Gábor

\title{
KÖLCSÖNÖS ELŐNYÖKÖN ALAPULÓ KAPCSOLATOK KIALAKÍTÁSA A FELSŐOKTATÁSI INTÉZMÉNYEK ÉS A MUNKAADÓK KÖZÖTT
}

A cikk a felsôoktatási intézmények (egyetemek és fôiskolák) és az üzleti szféra vállalatai közötti kapcsolatokkal foglalkozik. Az általános gazdasági és társadalmi aktualitások vizsgálatakor a szerzók tárgyalják a munkanélküliség, karrier, alumni, képzések, kutatás, innováció, szakmai gyakorlat és a hálózatok szerepét. Ismertetik továbbá egy sikeres intézmény (Massachusetts Institute of Technology) gyakorlatát a vállalati kapcsolatok vonatkozásában. Empirikus kutatásuk keretében 1389 db kérdôiv kiértékelését végezték el, amely a hallgatói és vállalati oldal elvárásaival, tapasztalataival foglalkozik a Pécsi Tudományegyetem Közgazdaságtudományi Karán szervezett szakmai gyakorlatok kapcsán. A tapasztalatokból kiolvasható, hogy mindhárom fél egyedi és kölcsönös elônyeinek (egyetem, hallgató, cég) biztosítása érdekében szükség van az e területen folyó tudományos kutatások támogatására, a legjobb gyakorlatok számbavételére és a tudományos eredmények gyakorlati szakemberekkel való megismertetésére, a céges tapasztalati eredmények oktatásba való integrálására. A soron következô időszak fontos feladatának látszik a bolognai képzésben megjelenố egyedi hallgatói életutak intézményi menedzselése, a tudatos karrierváltások beépítése az együttes gondolkodásba.

Kulcsszavak: egyetemi és üzleti szféra, munkaerópiac, kapcsolatok, hálózatok, szakmai gyakorlat, kompetenciák

„Úgy tünik, napjainkra az üzletemberek, gazdasági vezetók képzésére szakosodott felsófokú intézmények életgörbéje

az USA-ban elérte csúcspontját: ma már megújulásra lenne szükség. Hasonló folyamat hazánkban is megfigyelhetó."

(Barakonyi, 2009: 9.)

A tanulmány a felsôoktatás és a munkaerôpiac kapcsolatát ${ }^{1}$ elemzi, a szakmai gyakorlaton részt vevô hallgatói és munkaadói szereplők értékelésén keresztül. Az általános tapasztalatok feltérképezése támpontot adhat a késóbbi oktatási együttmúködések kialakítása, formálása során. Az intézményspecifikus sajátosságok ismertetése további hasznos gondolatokat közvetíthet. Hipotézisünk, hogy a szakmai gyakorlati rendszerek, karrierirodák, pályakövetési rendszerek és egyéb kapcsolatorientációt magába foglaló megoldások fenntartása és múködtetése egyaránt szolgálja a munkaadók számára a tehetségek megtalálását, toborzási funkció teljesülését, a készségfejlesztést, az újszerú tudás áramlását és az oktatás számára a munkaerő-piaci visszacsatolást. Egyszerúbben megfogalmazva: a három fél együttmúködése különbözó ismérvek mentén mindenki számára elốnyös.

A tanulmány fókuszában a felsôoktatási intézmények és a munkaerőpiac kapcsolatainak vizsgálata áll a gyakornoki rendszer mentén. A kijelölt fókuszt több irányból közelítjük meg (pl. külföldi példák, környezet elemzése, elvárások ismertetése révén). Az elemzés logikai struktúrája a vonatkozó szakirodalom releváns eredményeinek szintetizálásával, értékelésé- 
vel kezdődik, amellyel bemutatjuk a fókuszunk szempontjából legfontosabb tendenciákat. Ezután vázoljuk egy sikeres felsôoktatási intézmény gyakorlatát, öszszegezzük a partnerek együttmúködéséból származó előnyöket és felsoroljuk a konkrét együttmúködési formákat. A nemzetközi és hazai szakirodalmi kutatás konklúziójaként meghatározzuk a sikeres együttmúködés kulcsát jelentố szempontokat. Ezután kerül sor saját primer kutatási eredményeink ismertetésére, amelyet az összegzés és az elméleti és gyakorlati tapasztalatok összevetése alapján levont következtetések zárnak.

\section{Empirikus kutatásunk módszertana}

A Pécsi Tudományegyetem Közgazdaságtudományi Karának (PTE KTK) egyik fontos feladata, hogy a kar jelenlegi hallgatói számára egész évben szakmai gyakorlati lehetőségeket kínáljon, annak érdekében, hogy a hallgatók és az üzleti, intézményi szféra közötti kapcsolatot ezzel is erősítse. A szakmai gyakorlatok szervezését, teljes körú minőségbiztosítását, illetve dokumentálását a kar egyes egységei végzik (Kapcsolati Osztály, Karrier-tanácsadó Iroda). A kari tanács jóváhagyásával 2004-tól elindult a Szakmai, üzemi gyakorlat címú tárgy, amely biztosítja, hogy a 2006/2007-es tanév ôszi félévétől kezdve a szakmai gyakorlatok érdemjeggyel, 2 kreditként is elszámolhatóak legyenek. A teljesítés feltétele a hallgatói és vállalati kérdő́ivek kitöltése, amelyek alapján viszszacsatolást kapunk a szakmai gyakorlatról. Az ezzel kapcsolatos korábbi kérdőíves kutatásaink (Farkasné et al., 2008a, 2008b) tapasztalatait is beépítve végeztük el a legújabb összesített adatok lekérdezését, elemzését. 2005 ószétốl kezdődően 2010 tavaszáig összesen 463 hallgatótól érkezett be gyakornokonként 3 db kérdőív (hallgatói kérdőív a gyakorlat előtt és a gyakorlat után, valamint a vállalati kérdőív), így empirikus kutatásunk alapját 1389 db kérdőív képezi. A mintát a kifutó osztatlan képzés negyed-ötödéves hallgatói alkotják, tehát itt még nem jelennek meg a Bologna-rendszerben végzett kötelezô szakmai gyakorlati tapasztalatok.

A korábbi gyakorlat és felkészítés során a hallgatók önéletrajzokkal, motivációs levelekkel keresték meg a Karrier-tanácsadó Irodát (KTI), ahol az iroda munkatársai elvégezték a beadott anyagok szúrését, az adott céghez jelentkezố hallgatók rangsorolását (minden jelentkezố anyagának továbbításával). (Ezek a személyes egyéni közvetítések rendkívül idôigényesek voltak, ezért ma már nem múködik ez a KTI által alkalmazott eljárás.)

\section{Általános tendenciák}

A felsőoktatási intézmények egyik fontos célja, hogy a hallgatók a diploma megszerzése után minél gyorsabban el tudjanak helyezkedni. Napjaink tendenciái azonban megnehezítik e cél teljesülését. A hallgatóknak több problémával is szembe kell nézni egyszerre, és ezek a jellemzók hatással vannak egymásra is.

Elsóként említendő tényezô a felsőoktatás tömegesedése, amely az utóbbi évtizedekben ment végbe. Ez volt az egyik oka a diplomás munkanélküliség megjelenésének és növekvố arányának, valamint a bérek idóbeli vizsgálata alapján az is megállapítható, hogy 2000-ig óriási mértékben ${ }^{2}$ nôtt a foóiskolai és egyetemi diplomák piaci értéke (Kertesi - Köllő, 2006), 2000 után lelassult a növekedés, végül csökkenni kezdett a pályakezdô diplomások kereseti előnye. A felsôoktatásban részt vevő hallgatók összlétszáma 2005-ig folyamatosan emelkedett (a nappali tagozaton tanulók száma 2009-ig mutatott folyamatos növekedést a KSH adatai $^{3}$ alapján). A tömegoktatás azt eredményezte, hogy az oktatási intézmények hallgatói között is kiélesedett a verseny (Selmeczy, 2007). Véleményünk szerint ez a tendencia még erőteljesebben fog érvényesülni a Bologna-rendszerben. Összességében a tömegesedés tendenciája számos esetben megnehezítette a felsőoktatási intézményekból kikerülók elhelyezkedését. A felsôoktatás megnövekedett hallgatói létszámának különbözó egyéni és társadalmi hatásait az 1. táblázat foglalja össze (Szabóné, 2008).

\section{1. táblázat}

A felsóoktatás tömegesedésének hatásai

\begin{tabular}{|c|c|c|}
\hline & Egyéni szint & Társadalmi szint \\
\hline $\begin{array}{l}\text { Pozitív } \\
\text { hatások }\end{array}$ & $\begin{array}{l}\text { Könnyebb bejutás } \\
\text { az egyetemekre, } \\
\text { lehetőség a tanu- } \\
\text { lásra, tudásbővítés, } \\
\text { továbbképzés, } \\
\text { karrier }\end{array}$ & $\begin{array}{l}\text { Gazdaság fejlődése, } \\
\text { múveltség, kulturáltság, } \\
\text { szakképzettség növekedése, } \\
\text { széles körú oktatási-képzési } \\
\text { kínálat, csökken az alulkép- } \\
\text { zettek aránya }\end{array}$ \\
\hline $\begin{array}{l}\text { Negatív } \\
\text { hatások }\end{array}$ & $\begin{array}{l}\text { Elégedetlenség } \\
\text { az elhelyezke- } \\
\text { dési problémák } \\
\text { miatt, feszültség } \\
\text { a végzettségnél } \\
\text { alacsonyabb szintú } \\
\text { munka miatt, a } \\
\text { nem használt tudás } \\
\text { elfelejtése }\end{array}$ & $\begin{array}{l}\text { Diplomás munkanélküliség, } \\
\text { külföldre vándorlás, nem } \\
\text { hasznosuló tudásra fordított } \\
\text { képzési költség „,ablakon } \\
\text { kidobott pénz”, alacsonyabb } \\
\text { végzettségúekre gyakorolt } \\
\text { kiszorító hatás }\end{array}$ \\
\hline
\end{tabular}

Forrás: saját szerkesztés Szabóné Mojzes A. (2008): Tömegesedés a felsóoktatásban. Pécs: Oktatás és Társadalom Neveléstudományi Doktori Iskola, Pécsi Tudományegyetem 15. o. és Vincze Sz. (2009): A diplomások túlképzésének megnyilvánulásai. Új Pedagógiai Szemle, 8-9. sz. 47-70. o. alapján 
A második jellegzetesség, amely megnehezíti az álláskeresốk esélyeit, hogy bizonyos szakmák esetében több szakembert képeznek, mint amennyit a munkaerốpiac képes felszívni, míg más területen dolgozó szakemberekből kevesebbet képeznek, mint amennyire szükség lenne. Röviden: a felsőoktatás szakmastruktúrája nem fedi le teljesen a munkaerópiac elvárásait (Tóthné, 2008). A munkaerôpiacon egyszerre van jelen a munkanélküliség és a munkaeróhiány, a felsőoktatás pedig egyre kevésbé képes kielégíteni az elvárásokat és közvetíteni a megfelelố szaktudást (Kabai - Szabó, 2008). Az oktatáspolitika gyenge pontjai a munkaerópiacon mutatkoznak meg, olyan társadalmi-gazdasági feszültségeket okozva, mint a munkanélküliség, inaktivitás, bérarányok gyors változása, erôforrások pazarlása és elégedetlenség (Polónyi - Tímár, 2004). A Bologna-folyamat egyik célkitúzése, hogy a felsőoktatás a munkaadói elvárásokat minél jobban kielégítse.

A harmadik tendencia összefügg az előzôvel, és a lényege, hogy a turbulensen változó környezetben áttevớdik a hangsúly a megszerzett tudásról a kompetenciákra, előtérbe kerül a rugalmasság, változékonyság követelménye. Ennek oka a gazdaság globalizációja, az információk mennyiségének gyors növekedése, a tudás folyamatos megújítási igénye és a multikulturális társadalmak kialakulása (Dinya, 2002). Mivel folyamatosan változnak a munkaerópiac kompetencia-elvárá$\mathrm{sai}^{4}$, a felsốoktatás nehezen tud alkalmazkodni a kívánt képzési és kimeneti követelményekhez. Ez a probléma felveti a felsôoktatás és a munkaerópiac folyamatos interakciójának szükségességét.

Mindhárom tendencia együttesen érvényesül, így a pályakezdő diplomások elhelyezkedési esélyei romlottak, ami társadalmi és nemzetgazdasági szinten is problémákat okoz (pl. munkanélküliség, elvándorlás, inaktivitás). A felsőoktatási intézmények célja, hogy javítson ezen a helyzeten, és erre több módszer is rendelkezésre áll.

Az egyik ilyen lehetőség a végzett hallgatók tovább- és átképzése az igényeknek megfelelően. A diplomás pályakezdók oldaláról is megnyilvánuló jelenség az oktatásba történô „menekülés”, amennyiben nem tudnak elhelyezkedni (Vincze, 2009). Ez a törekvés vezet el az élethosszig tartó tanulás fogalmához, amely szorosabbra fúzi a felsőoktatás és a munkaerópiac közötti hallgatói áramlást (pl. a munkahelyén úgy tud magasabb pozíciót betölteni, ha újabb képzésben vesz részt).

A másik megoldás a munkaadókkal történő együttmúködés olyan formája, amelyben biztosított az egymással versengó hallgatók többleterőfeszítésének lehetősége. A hallgatóknak saját érdekükben, elhelyezkedési esélyeik javításáért a formális képzésen túlmenóen egyéb erőfeszítéseket kell tenniük, hogy kitünjenek (Szalka - Czipf, 2008). A kapcsolatok kialakítására nagyon jó lehetôséget teremt a korábban említett szakmai gyakorlat, vagyis felértékelődik a gyakornoki munka szerepe (Munkácsy, 2004). Ez a fajta együttmúködés a hallgatók és a vállalatok között jó alkalmat teremt a személyes kapcsolat kialakítására, egymás megismerésére, adott esetben a jövóbeni munkaeró „kinevelésére”. Fontos hozzátenni, hogy csak abban az esetben lehet kiaknázni ezeket az előnyöket, ha a hallgatók fogadása és munkájuk megszervezése tudatosan történik. A tervszerú gyakornoki munka különös gondossággal való biztosítása a hallgatók számára ugyan többletmunkát jelenthet a cégeknek, de ez a befektetett energia bôségesen meg fog térülni a későbbiekben. Sok vállalat esetében azonban szükséges rossz a gyakorlat biztosítása, bürokratikus pluszfeladatnak gondolják, így nem aknázzák ki az együttmúködésben rejlő lehetőségeket. A cégek kis hányada fordít figyelmet a gyakornoki programokra, betanításra, továbbképzésre és készségfejlesztésre. További nehézséget okoz a cégek finanszírozási kötelezettsége a Bologna-rendszerben tanuló BA-hallgatók kötelezố szakmai gyakorlata kapcsán.

Összegezve a három legfontosabb szereplő - munkáltatók, felsőoktatási intézmények és (hallgatókból lett) munkavállalók - együttmúködése (1. ábra), illetve hatékony kommunikációja megalapozhatja a továbblépést, a fenti problémák megoldását. A múködő közvetítơrendszerek konkrét példái (Majó, 2000 - Tóth, 2007) mutatják annak pozitív regionális gazdasági hatásait (pl. munkaerő megtartása a régióban) is.

1. ábra

\section{Kapcsolódási lehetőségek az egyes szereplók között}

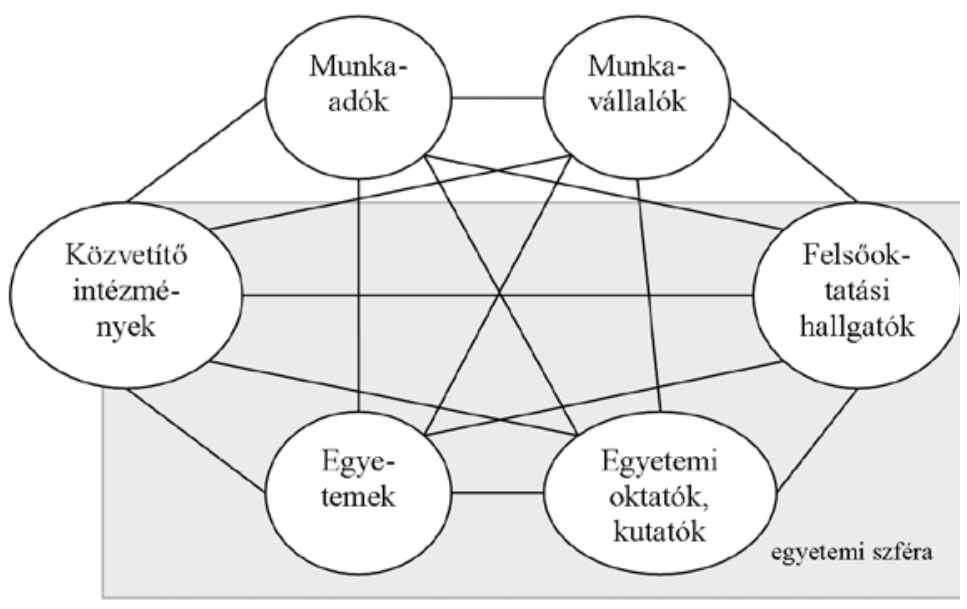

Forrás: saját szerkesztés 


\section{A felsôoktatás és a munkaadók közötti kapcsolat}

A felsőoktatási célrendszerek fókuszába az értékteremtésnek kell kerülnie. A leginkább célravezetô stratégiában mind a három értékkategóriának (oktatás, kutatás, közösségi kapcsolatok) szerepelnie kell, ha nem is teljesen azonos mértékben (Barakonyi, 2003). A vállalati igények alapján egyre inkább erôsíteni szükséges a gyakorlati fókuszt, ezáltal lehetne igazodni a munkaadói elvárásokhoz (Barakonyi, 2009). Az ezen elveknek való megfelelésben komoly szerepet tölthetnek be a munkaadói és a felsôoktatási szféra között létrejövő kapcsolatok, amelyek segíthetnek mindkét fél számára a stratégiai szintú alkalmazkodásban, a versenyképesség erősítésében.

Majó (2000) szerint az állásbörzék, a karrier központok, valamint a hallgatói követési rendszerek megalapozhatják a kapcsolatot a felsőoktatás és a munkaerôpiac között. Ennek a sikerességét azonban leginkább a konkrét szereplók aktivitásának mértéke határozza meg. Más kutatók véleménye alapján az együttmúködés leggyakoribb megvalósítási formája a felsôoktatási intézmény kutatómunkájának támogatása, illetve a céges prezentációk (Tóth, 2007). Vizsgálataink és elemzéseink alapján a következókben feltárjuk és bemutatjuk a véleményünk szerint legfontosabb és legsikeresebb együttmúködési formákat és ezek elônyeit.

A munkaadói szféra és a felsôoktatási intézmények között különbözô típusú és erôsségú kapcsolati formák jöhetnek létre, amelyek múködôképességét, hasznosságát jelentôsen befolyásolja az, hogy az együttmúkködő felek milyen konkrét tartalommal töltik meg azokat. Mielótt megvizsgáljuk a hazai helyzetet és bemutatjuk a legjellemzóbb hazai megoldásokat, felvázoljuk az MIT $^{5}$ (véleményünk szerint példamutató) gyakorlatát (Wright, 2008).

\section{Egy sikeres intézmény gyakorlata}

Az Egyesült Államokban múködô MIT vállalati kapcsolatainak elemzése alapján megállapították a kutatók, hogy az együttmúködés oka a felsőoktatási szférában a különbözó szereplók között, hogy egyrészt csökken az állami finanszírozás lehetősége a felsőoktatásban, másrészt nagyon komoly igény mutatkozik a vállalatok részéról az egyetemekról származó innovációs lehetóségek, új kapacitások, tudástranszffer iránt. Ezen tényezók együttes jelenléte kitúnó alkalmat teremt az együttmúködésre (Wright, 2008). Ehhez hasonló a helyzet hazánkban is, ahol az állami finanszírozás a több éve nem növekedő hallgatói normatíván keresztül fokozatosan próbálja csökkenteni a felsőoktatásnak juttatott források valós nagyságát. Az egyetemi innovációs kapacitások iránti érdeklődésnek számos jó példáját látjuk Magyarországon is, bár ezek „tömegesedése” még nem jellemző. Polónyi kutatásai alapján a hallgatói költségtérítés mellett a kutatási bevételek ${ }^{6}$ ítélhetốk az egyetemek legfontosabb bevételi elemének (Polónyi, 2009). A projektszerú finanszírozások és a nagy projektek aránya megnövekedett, azonban kevés olyan egyetem van, ahol jelentôs szerepet játszanak a kutatási bevételek.

Ehhez kapcsolható az ,akadémiai kapitalizmus” jelensége, amely szerint a különbözó szereplők, úgy mint a karok, hallgatók, az adminisztráció és az oktatók az állami eszközrendszer felhasználásával olyan új tudáshalmazt hoznak létre, amely összeköttetést teremt a felsőoktatási intézmény és a gazdasági szféra között. Mindezek hatására új együttmúködési hálózatok alakulnak ki az állami és a magánszféra között. (Slaughter - Rhoades, 2004). A döntő fontosságú kérdés, hogy milyen tartalommal sikerül megtölteni ezt az együttmúködést, mennyiben sikerül az eltéró irányultságú szereplók között kapcsolatot teremteni. Az érdekek kölcsönössége tisztábban jelenik meg egyetemünk húsz doktori iskolájában.

Az együttmúködés kialakítása során figyelembe kell venni azt is, hogy a két szférában jelentôsen eltéró a kultúra, a mentalitás. A vállalatoknál jellemző egyfajta rövid távú szemlélet, amely jelentôs profitorientációval párosul, mindez biztosítja az eredményeket, a jövedelmezôséget, az üzleti életben jellemzó versenyben való fennmaradást. A felsőoktatási szereplő́k körében inkább a hosszú távú szemlélet dominál (kevésbé fontosak a rövid távú sikerek, gyors győzelmek), mindez párosul a kutatói mentalitással. A MIT esetében számos kapcsolódási lehetôséget érdemes számba venni (Wright, 2008). Ezek első csoportját alkotják a hagyományos megoldások:

- kiválasztás, toborzás az egyetem végzősei közül,

- közös kutatás indítása,

- technológiatranszfer az egyetemról a vállalat felé,

- vállalati vezetốk továbbképzése ${ }^{7}$,

- alumni kapcsolatok,

- szakmai gyakorlatok.

Mindezeket kiegészítik további újszerü, innovatív formák:

- projektek kiszervezése az egyetemre,

- licencek vásárlása az egyetemról,

- mérsékelt díjazású tanácsadás igénybevétele az egyetemról,

- specifikus, vállalatra szabott, aktuális, új megoldások keresése, felhasználva az egyetem technológiáját, eszközeit és humán kapacitásait. 
A bemutatott kapcsolódási lehetőségek több hazai felsôoktatási intézmény esetében is megjelennek, de egyes együttmúködési formák a jövôben még tovább bôvíthetôk.

\section{Az együttmúkködés elônyei}

A bemutatott példánál két fontos előnyt emeltünk ki, egyrészt a felsőoktatás részérôl a finanszírozási források bôvítését, másrészt a vállalatok oldaláról az innovációs lehetőségek, tudástranszfer és a kapacitások iránti igényt (Wright, 2008). Akár ezen kettő tényezô fontossága is bizonyítható fordítottan is: a vállalatok számára előnyös és sokszor kötelezô előírás (európai uniós forrásokból történô) fejlesztési projekteknél együttmúködő akadémiai szférából származó partner igénybevétele, vagyis a finanszírozási lehetőségeket bóvítheti egy együttmúködés számukra

is. A felsőoktatásban dolgozók számára ugyanúgy fontos lehet a vállalati tudás, gyakorlat felmérése, és ennek felhasználása az oktatás fejlesztése során a gyakorlati jelleg erôsítése érdekében is.

A felsőoktatás és a munkaerôpiac kapcsolódásának és intézményrendszerének három lehetséges elvi eredményét érdemes kiemelni: a régió meghatározó cégei a helyi állásbörzéken történố megjelenéssel kapcsolatot építenek (tájékozódás a potenciális munkaeró-állomány képzési színvonaláról, szakmai ismereteiról, illetve a diákok képességeiról). Ezenfelül a régióban múködő cégek a Karrier-tanácsadó Irodán (vagy más közvetítő intézményeken) keresztül folyamatosan kereshetnek diplomás pályakezdôt a felsőfokú végzettséget igénylő munkakörökbe. Továbbá az utókövetési rendszeren keresztül folyamatos visszajelzést kaphat a felsôoktatási intézmény és a hallgatók (Majó, 2000). Ezek az eredmények bővíthetőek egyéb más együttmúködési formák alkalmazása esetén.

\section{Konkrét együttmúködési formák}

Az egyetemek és a vállalatok számos módon interakcióba léphetnek egymással, s ezen események során nagyon sok esetben a hallgatók is érintettekké válhatnak. A felsóoktatás és az üzleti szféra közötti kapcsolat kialakítására tehát többféle módszer létezik, ilyen lehet a kutatói munka, céges prezentációk, állásbörzék, valamint az olyan rendezvények, mint például az MKB Professzori Klub a PTE egyetemi tanáraival, kutatásfejlesztési együttmúködések, befektetési és gazdaságfejlesztési együttmúködések stb. A további lehetôségeket a 2. ábra jeleníti meg a gyakoriságok sorrendjében.

2. ábra az együttmúkködés jellege szerint $(\%)$

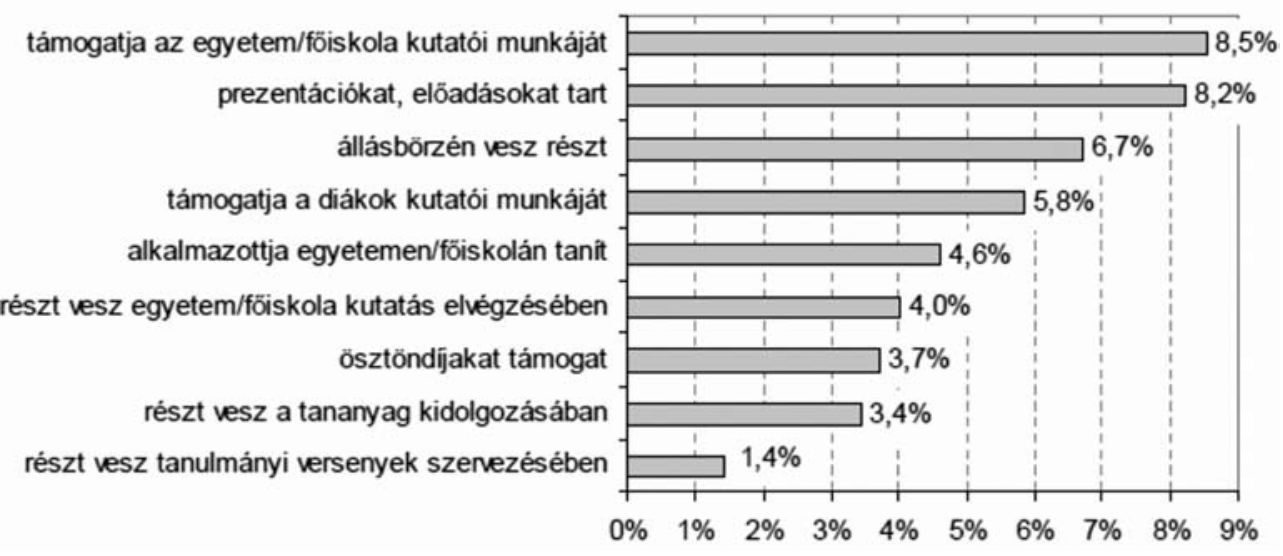

Forrás: Tóth István: Diplomás pályakezdók és egyetemi, fóiskolai karok vállalati szemszögból - 2007 Budapest: MKIK Gazdaság-és Vállalkozáselemzó Intézet Kutatási Füzetek 2007/1. 94. o.

Tóth (2007) kutatása alapján minden negyedik vállalat kapcsolatban állt valamilyen formában a felsőoktatással. A múszaki területen a legjellemzóbb az együttmúködés, de gyakori a gazdasági karok esetében is. A PTE KTK mindezeket kiegészíti még olyan együttmúködési formákkal is, amikor a cégek képviselối jönnek képzésre az oktatási intézményekbe, ahol „megtermékenyítik" a mindenkori tantervi foglalkozásokat.

Munkaadói szempontból nem véletlen, hogy ilyen gyakoriak a munkaerópiac és a felsőoktatás, valamint a hallgatók között fennálló kapcsolatok. A vállalatoknak harcolniuk kell a kimagasló tehetségekért (Farkasné Lóránd, 2007). A vállalatok számára egyre jobban előtérbe kerül a megfelelő kompetenciákkal rendelkező tehetségek kérdése, nagyon fontos ugyanis a tehetségek felkutatása, megszólítása, kiválasztása és megtartása. Összességében a cégeknek érdekében áll a legjobb potenciális munkaerô vonzása (Tóthné, 2008). Az együttmúködési eszközök és egyéb módszerek nagyon színes tárházzal rendelkeznek. A cégek ezeket a találkozási lehetôségeket kihasználva megismerhetik a hallgatók képességeit, szakmai ismereteit, ezek színvonalát, és így adatbázist építhetnek fel. Karunkon készül a végzett hallgatók rangsorolásának szakértői rendszere. 


\section{Lehetséges együttmúködési formák a munkaadók és a felsôoktatási intézmények között}

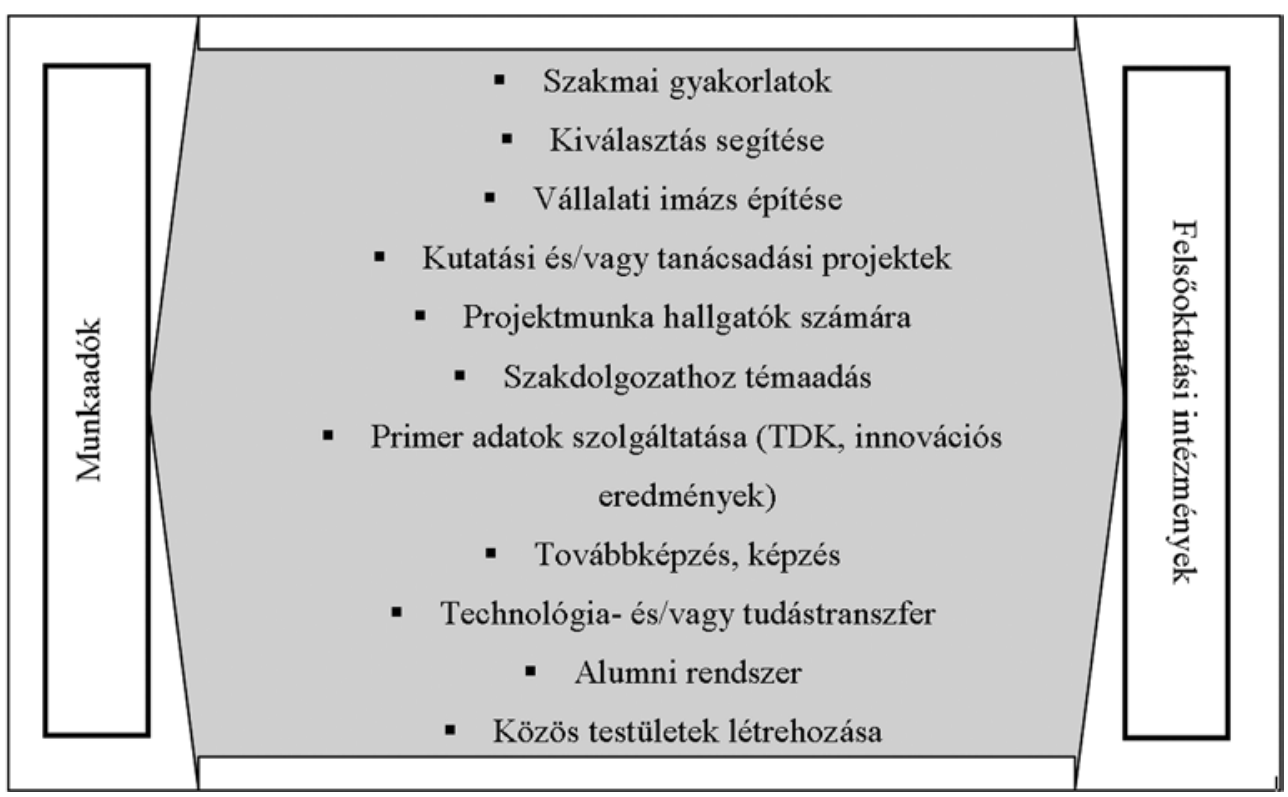

Forrás: saját szerkesztés

A tényleges együttmúködési lehetőségek számos formája ismert (3. ábra). Ezek közül jelenleg az egyik legaktuálisabb a (hatályos szabályozás alapján) kötelező szakmai gyakorlati rendszer, amely szerint egyes képzések esetén a BA-diploma megszerzésének feltétele egy szemesztert felölelô szakmai gyakorlat teljesítése (pl. a közgazdasági képzések üzleti szakjainál). Ez az együttmúködés egyrészt törvényi kényszer által indukált, másrészt a tömegoktatás keretei között jelentôs feladatot ró a felsôoktatási intézményekre (illetve ahol önálló szervezése folyik a szakmai gyakorlatoknak, ott a hallgatókra). Jelenleg az elsố olyan évfolyam tapasztalatait ismerjük, amely ebben a rendszerben végzi tanulmányait. A visszajelzések alapján elmondható, hogy számos munkaadó jó lehetőséget látott az átmeneti, esetleges munkaeróhiány mérséklésére a szakmai gyakorlatos foglalkoztatásával, esetenként jellemző volt az önálló projektmunka allokálása a hallgató számára. Egyes esetekben viszont kifejezetten negatív viszszajelzések érkeztek (bár a rendszerben való részvétel a munkaadók számára nem kötelezó). Fontos, hogy a vállalatok foglalkozzanak a szakmai gyakorlatok elókészítésével, konkrét forgatókönyveket készítsenek és/ vagy kövessenek ennek kapcsán. A társadalmi háttér sem igazán kedvezó a szakmai gyakorlatoknál: a vállalatok, intézmények részéról a hallgatók gyakorlati foglalkoztatására nézve a multinacionális cégekhez képest sokkal kevésbé jellemző a megfelelő fogadókészség. A gyakorlat alatt nincs elegendó gondolkodtató, elem-
3. ábra zést és problémamegoldást igénylő, kihívást jelentô feladat (333 fó BA szakmai gyakorlati beszámoló alapján). Pénzügyi anomáliákat okoz, hogy a profitorientált szféra vállalatainak az egybefüggô 12 hetes gyakorlat során fizetniük kell a hallgatóknak munkabért, míg a hallgatók után járó normatívát az egyetemek kapják meg (igaz, nem az aktuális tanévben, hanem csak késóbb). Továbbá a közszféra szereplóinek nem kell fizetniük a hallgatóknak munkabért.

Jelentős, hazánkban még csak kevés helyen tudatosan kiaknázott lehetőségeket rejt magában egy jól múködő alumni rendszer létrehozása, amely a végzett hallgatókon keresztül megteremtheti az egyetem, a munkaadók és a munkavállalók közötti kapcsolatok intézményesített, folyamatosan múködő formáját, lehetőségét. Az Egyesült Államokban ennek az intézménynek jóval nagyobb a jelentősége, mint nálunk. Ott a volt diákok részéról érkezô pénzbeli támogatás és az egykori hallgatók felvételizô gyermekeinek nyújtott intézményesített protekció jelenti a legfontosabb előnyöket. Ezeket egészíti ki még a végzettek közötti kapcsolattartás intézményesítése, az egyetem karrier-tanácsadói szolgáltatása volt diákjai számára, segítségnyújtás álláskeresóknek, továbbá közösségi programok szervezése (Nagy, 2007) .Ezen szolgáltatások között minden szereplő megtalálja a számára fontosat és értéket jelentóket.

Az intézményesített, általános kapcsolati formák mellett komoly szerepet játszanak az intézményfüggó, sokszor személyfüggó megoldások is. Ide sorolható a vállalati projektmunka hirdetése a hallgatók számára, közös kutatási együttmúködés oktatók és hallgatók bevonásával, tanácsadási projekt hirdetése egyetemi oktatók, hallgatók számára, vállalati kiválasztást elősegítő rendezvények, programok (állásbörze, karrier-pizza, cégbemutató előadás stb.) létrehozása, továbbképzési tanfolyamok szervezése vállalati vezetôk és munkatársak számára az egyetemeken, licencek vásárlása, technológia- és tudástranszfer megvalósítása az egyetemról a vállalatok felé és fordítva. Ezek a megoldások mindig a felmerülő igények, adott helyzetben jelen lévő kap- 
csolatrendszer és kapacitások vagy kapacitásigények alapján formálódnak, alakulnak meg és bomlanak fel. Folyamatos biztosításuk érdekében fontos szerepet játszanak azok az egyetemi irodák (osztályok) és vezetốk, akiket a vállalati kapcsolatok gondozásának feladatával bíznak meg.

Távolról kapcsolódhat még ehhez a témához a végzett hallgatók pályakövetése vagy életpálya-vizsgálata, amely inkább a felsőoktatás és a hallgatók közötti kapcsolatról szól, de ez a hosszú távú szakmai kapcsolat fenntartásához és erősítéséhez is szervesen hozzájárul. (Majó, 2000) A diploma értékének igen jó méróje lehetne, ha pontosan ismernénk, hogy melyik egyetem diákjai tudnak leg-

könnyebben (leghamarabb) elhelyezkedni végzettségüknek megfelelố állásban, és mekkora fizetést tudnak elérni munkaadójuknál. A hazai felsőoktatási intézményeknek igen kis hányada (5-10\%) végez rendszeres utókövetést, vagyis így nem rendelkezünk összehasonlítható adatokkal. Továbbá a végzettek körében jellemzóen alacsony a válaszadási hajlandóság (1640\%) (Pálmai, 2009), ami azt eredményezi, hogy a meglévô felmérések eredményeit is csak fenntartásokkal szabad elfogadni.

A munkaadó szervezetek kapcsolata a felsőoktatási intézményekkel három csoportra osztható: laza (távoli), közepes és szoros. A legtöbb szervezet távoli kapcsolatot tart. A közepes kapcsolat a részben vagy egészben külföldi tulajdonú vállalatok esetében mutatható ki leginkább. Szoros kapcsolatot a legtöbb esetben a közszféra képviselóivel, illetve a nagyobb hazai cégekkel alakítottak ki a felsőoktatási intézmények (Polónyi, 2007). A hazai felsőoktatásban egyre inkább versenyelőnyt fog jelenteni e kapcsolatok szorossága.

\section{A sikeres együttmúkiödés kulcsa}

A fentiekben bemutatott fókusszal rendelkezó együttmúködés sikerességéhez szükséges, hogy a kapcsolatok építése során a hosszú távú személet érvényesüljön. A kooperációkba mindig be kell vonni a vállalati szereplók részéról a felsố vezetést is. Ezenfelül az együttmúködés esetén nem érdemes csak izolált problémákra, egyszerú technikai feladatok megoldására fókuszálni, ennél eredményesebb lehet, ha a kooperáció középpontjába inkább stratégiai kérdések és területek kerülnek. Továbbá fontos felismernie a vállalati vezetốknek, hogy a felsôoktatási intézményekbő́l nem kész innovációkat vagy termékeket vásárolhatnak meg, hanem kompetenciát és tudást, amelyek együttesen képesek elósegíteni az innovációkat (Wright, 2008). Ezek a tényezók együttesen hozhatják létre a sikeres együttmúködést az egyes szereplók között, amelyben nem csak az erőforrás-kötelékek játszanak fontos szerepet, hanem a személyes kötődések és a tevékenységi kapcsolatok is (4. ábra).

4. ábra

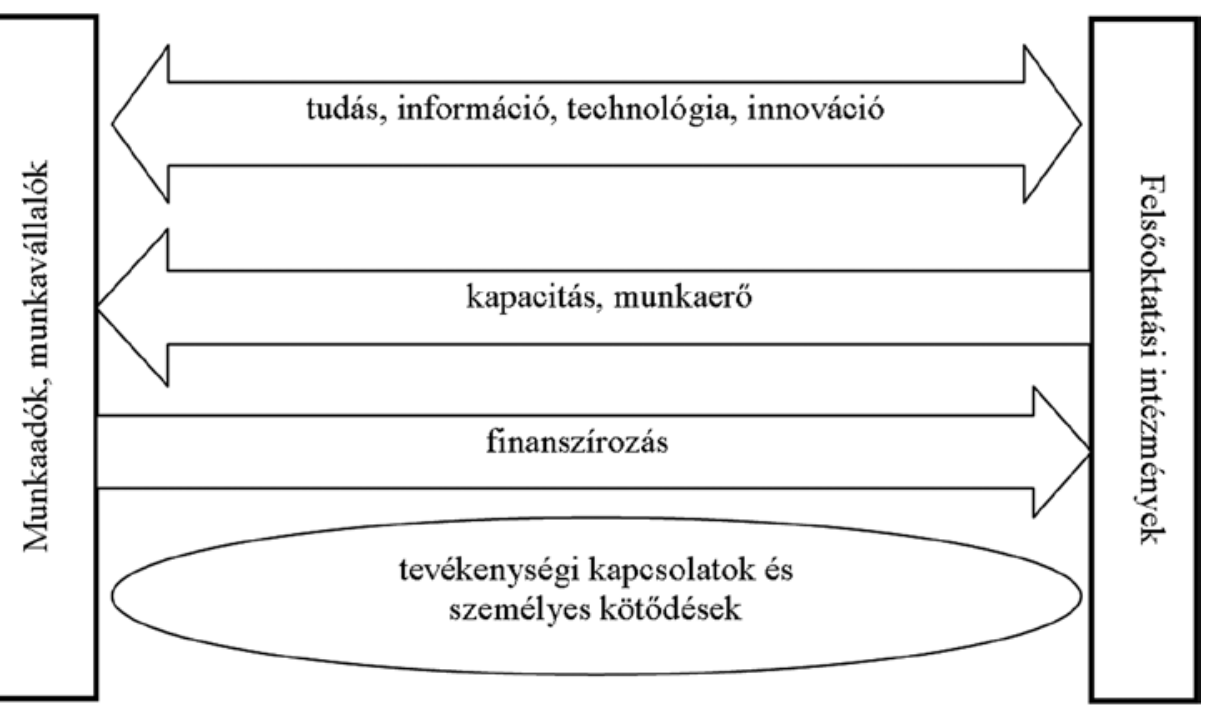

Forrás: saját szerkesztés

Az egyetem (közgazdaságtudományi kar) mai komoly szakmai tudásán túl elengedhetetlen a szereplók kompetenciakészletének fejlesztése, amely kulcsfontosságú a tőlük elvárt szerepek sikeres betöltéséhez.

\section{Az empirikus kutatás eredményei}

A fiatal pályakezdốk tudása és képességei nem fedik le teljes mértékben a munkáltatói elvárásokat, vagy bizonyos esetekben nem felelnek meg a követelményeknek. Ismereteik elsôsorban elméleti felkészültséget bizonyítanak, amelyeket azonban nehezen tudnak a gyakorlatban is alkalmazni. Manapság a szakmai felkészültségen túl - és legalább akkora súllyal - figyelik a munkáltatók az állásra pályázók önismeretét, magabiztosságát, kommunikációs képességét és interperszonális adottságait. Az elhelyezkedés sikerét tehát a személyes jellemzók jobban befolyásolják, mint a végzettség. 
5. ábra a magasabb szint felé haladva növekszik meg a kon-

A legfontosabb képességek a gyakornoki munka végzéséhez a hallgatók szerint a szakmai gyakorlat elótt

(említések aránya, \%, $\mathrm{N}=463$ )*

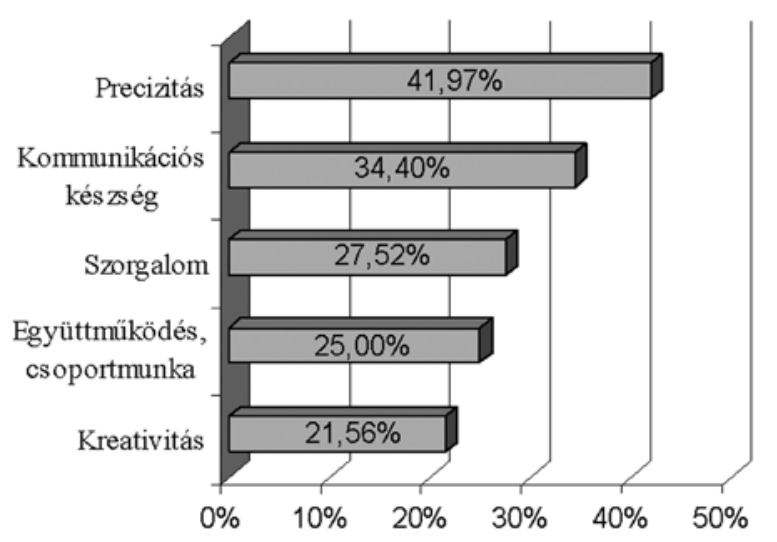

*Egy hallgató maximum három képességet nevezhetett meg.
Ezt a felsôoktatási intézményeknek is jobban figyelembe kell vennie a jövóben (Benedek, 2004). Növekszik a szociális képességek szerepe, és a kritikai gondolkodás, problémamegoldás, információ megszerzésének, kezelésének és kiértékelésének fontossága, valamint az, hogy miként tud valaki bármilyen szociális-kulturális környezetben viselkedni (Dinya, 2002). Továbbá megállapítható, hogy kezdốként csak keveseknek lesz szükségük újító, innovatív készségekre, inkább elôtérbe kerül az, hogy együttmúkködjenek, és könnyen beilleszkedjenek a munkatársak közé (Kabai - Szabó, 2008). Ez látszólag ellentétben áll azzal a korábbi következtetéssel, hogy gyorsan változó világunkban rugalmas készségekkel rendelkező munkaerőre van szükség. Saját tapasztalataink alapján azonban elmondható, hogy a gyors tanulási képességek révén folyamatosan változtatnia, fejlesztenie kell képességeit a munkavállalóknak is, de oly módon, ahogy azt a felettesei, a munkaadói megkívánják, és pályakezdőként még ne legyen olyan szándéka, hogy megreformálja a vállalat múködését. Azaz a vállalati hierarchia különböző szintjein más-más arányban jelennek meg a megkövetelt készségtípusok, és jellemzően cepcióalkotáshoz szükséges képességek szerepe.

Saját empirikus kutatásunk eredményeképpen felmértük a hallgatók és a vállalatok szakmai gyakorlattal kapcsolatos preferenciáit. A gyakorlattal kapcsolatos elózetes hallgatói elvárások feltérképezésekor megállapítottuk, hogy a hallgatók elsősorban a precizitást gondolják a sikeres gyakornoki munka alapjának, ezt követi a kommunikációs készség, és harmadik helyen szerepel a közel azonos szinten álló csoportmunka, szorgalom és kreativitás is. A részleteket az 5. ábra jeleníti meg.

A hallgatók a gyakorlat előtt félelmeikról is nyilatkoztak, s ezek alapján egyértelmúen a beilleszkedéssel kapcsolatos félelmek kapták a legnagyobb hangsúlyt.

6. ábra

A hallgatók félelmei a gyakorlat elốtt

(említések aránya, \%, $\mathrm{N}=463$ )*

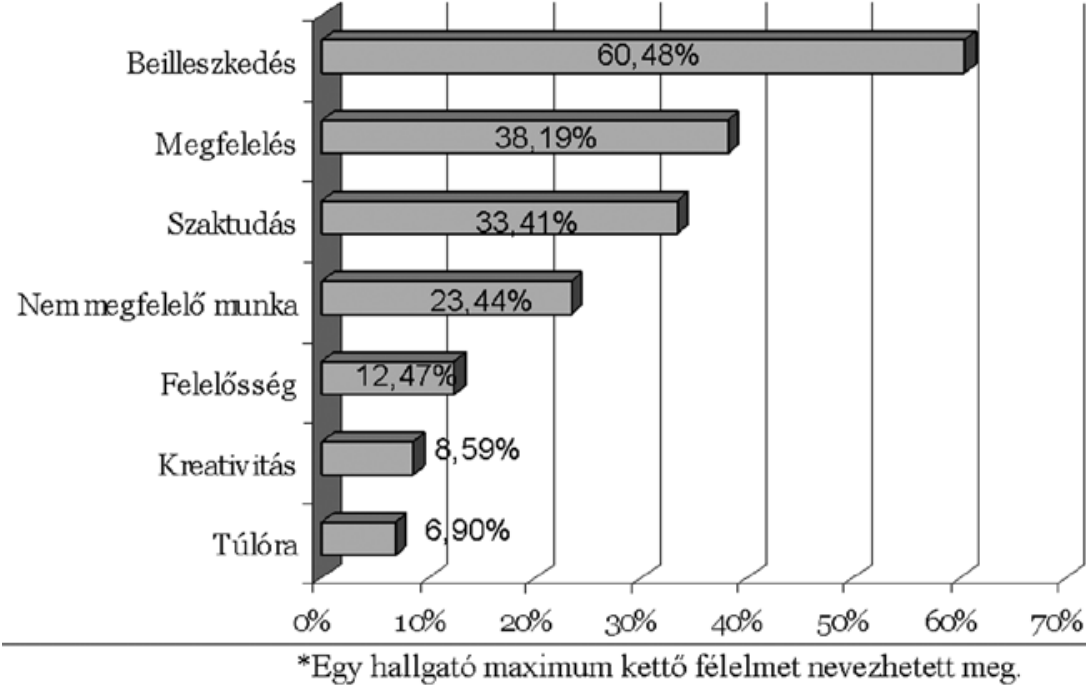

A hallgatók félelmei a gyakorlat elôtt, tanévenkénti bontásban (említések aránya, \%, $\mathrm{N}=463$ )*

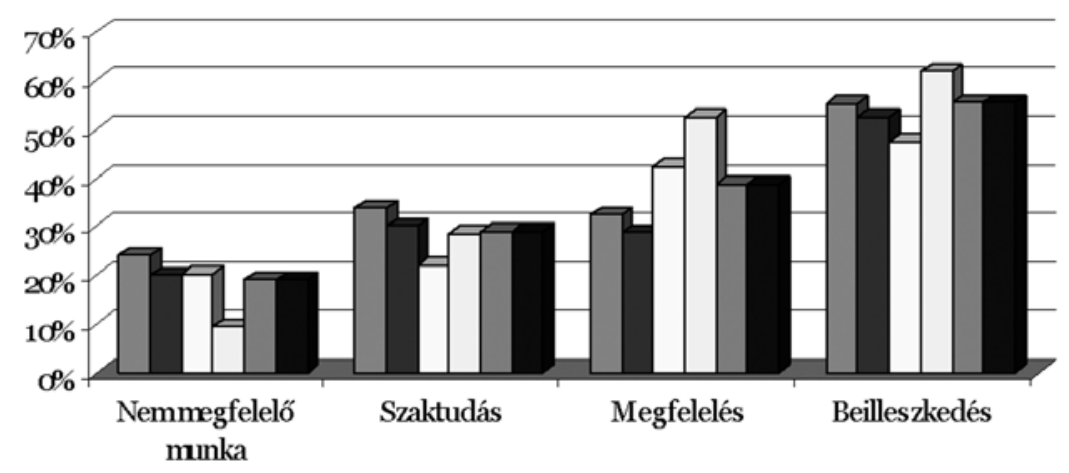

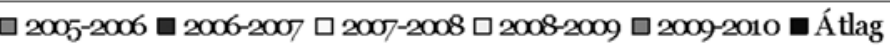

*Egy hallgató kettő félelmet nevezhetett meg. 
Ezen túlmenóen tartottak attól is, hogy nem tudnak megfelelni a munkaadói elvárásoknak, és nem lesz elegendő az egyetemen elsajátított szaktudásuk sem. A hallgatók közel egynegyede attól is félt, hogy nem lesz számára megfelelő a munka, nem azzal fog foglalkozni, amivel szeretne, amihez ért. A 6. ábra mutatja a százalékos megoszlásokat.

A hallgatói félelmeket tovább elemezve, ha tanévekre lebontjuk az összesített eredményeket, észre lehet venni, hogy az egyes félelmek közötti sorrend öt tanéves viszonylatban stabilnak mondható (7. ábra). Az ábrán szerepló ismérveket az átlagértékek alapján állítottuk növekvő sorrendbe.

Nemcsak a munkáltatók, hanem a hallgatók is megfogalmazták saját elvárásaikat a szakmai gyakorlattal kapcsolatban (8. ábra).

A 8. ábrán elsố helyet foglal el a hallgatók azon vélekedése, hogy a gyakorlat idôtartama alatt elsôsorban ki szeretnék próbálni a gyakorlatban az egyetemen megszerzett elméleti ismereteiket, és alkalmazni szeretnék azokat. Nagyon fontos, hogy a hallgatók fele meg szeretné ismerni a szervezetet, annak munkafolyamatait és a szervezet által képviselt szakterületet. Az eddigi ismeretek alkalmazásán túl egyéb gyakorlati ismereteket is szeretnének gyứjteni, fontos számukra a munkatapasztalat, és több mint a hallgatók egynegyede kiemelte, hogy jövőbeli lehetôségeket lát a szakmai gyakorlatban. Ez az adott vállalatnál dolgozó munkatársakkal kialakított kapcsolatokat, azok késóbbi kamatoztatását jelenti, valamint azt, hogy lehetôséget látnak abban, hogy a szakmai gyakorlat végeztével állásajánlatot kapjanak a cégtól.
8. ábra

A hallgatók elvárásai a gyakornoki munkától a szakmai gyakorlat elốtt (említések aránya, \%, $\mathrm{N}=463$ )*

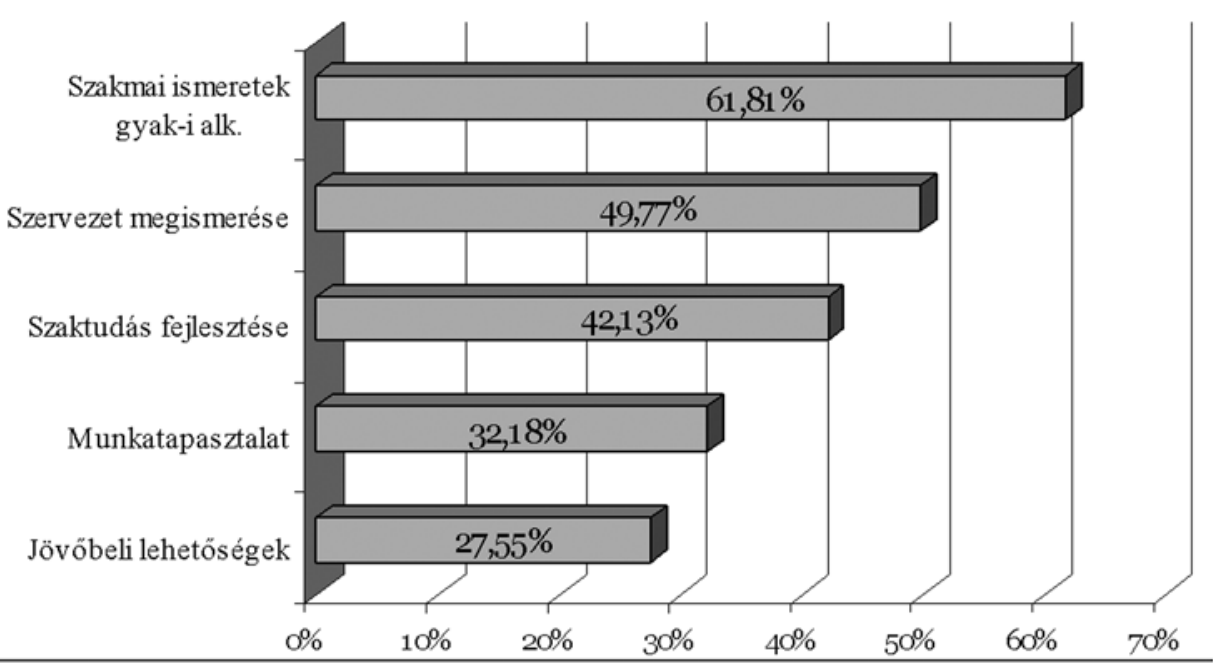

*Nem határoztuk meg, hány elvárást lehet megnevezni.

Forrás: saját szerkesztés

A gyakorlat után kitöltött kérdőívekból kiderült, hogy a hallgatók elôzetes elvárásai nagymértékben teljesültek, valamint a korábbi félelmek alaptalanok voltak. A legtöbb hallgató azt emelte ki elsôdlegesen, hogy alkalma adódott arra, hogy megismerje a szervezetet, munkafolyamatokat, s ezáltal képet kapjon arról, hogy az adott területen (pl. pénzügyi, logisztikai, könyvelői stb.) melyek a sajátosságok (9. ábra).

Az elvárások között elsố helyen szereplô szaktudás gyakorlati alkalmazás 41,9\%-os említési arányt ért el a vizsgált sokaságon belül, és közel azonos szintet ért el az a megállapítás, amely szerint a hallgató teljes mér-

9. ábra

Hallgatói tapasztalatok a gyakorlat után (említések aránya, \%)*

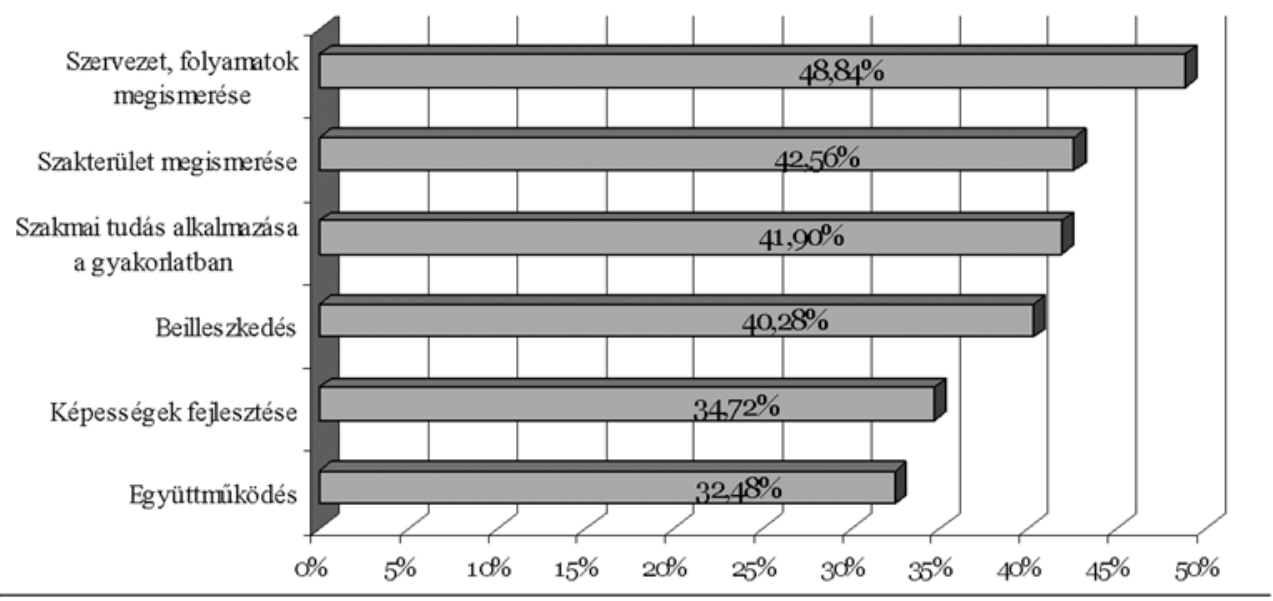

*Nem határoztuk meg, hány tapasztalatot lehet megnevezni.

Forrás: saját szerkesztés 
tékben be tudott illeszkedni a munkatársak közé. Továbbá a hallgatók képességfejlődést is tapasztaltak, és jól együtt tudtak múködni a kollégákkal.

Munkaadói oldalról a kérdőívek alapján azt lehet elmondani, hogy a hallgatókat a legtöbb esetben a pontosság jellemezte, ami tükrözi a hallgatók gyakorlat előtti vélekedését a gyakornoki munkához szükséges kompetenciákról (10. ábra).
Második helyen szerepel a szorgalom mint jellemző hallgatói tulajdonság, és körülbelül azonos szintet ért el a vállalatok által kiemelt szempontok között az érdeklôdés, megbízhatóság, a jó hozzáállás, együttmúködés, kreativitás és a kommunikációs képesség.

A vállalati oldalról megnyilvánuló vélemények nemcsak a hallgatókra, hanem a hallgatók által elvégzett munkára is kiterjedtek (11. ábra).
Vállalati jellemzés a hallgatók legfontosabb képességeiról (említések aránya, \%, $\mathrm{N}=463$ )*

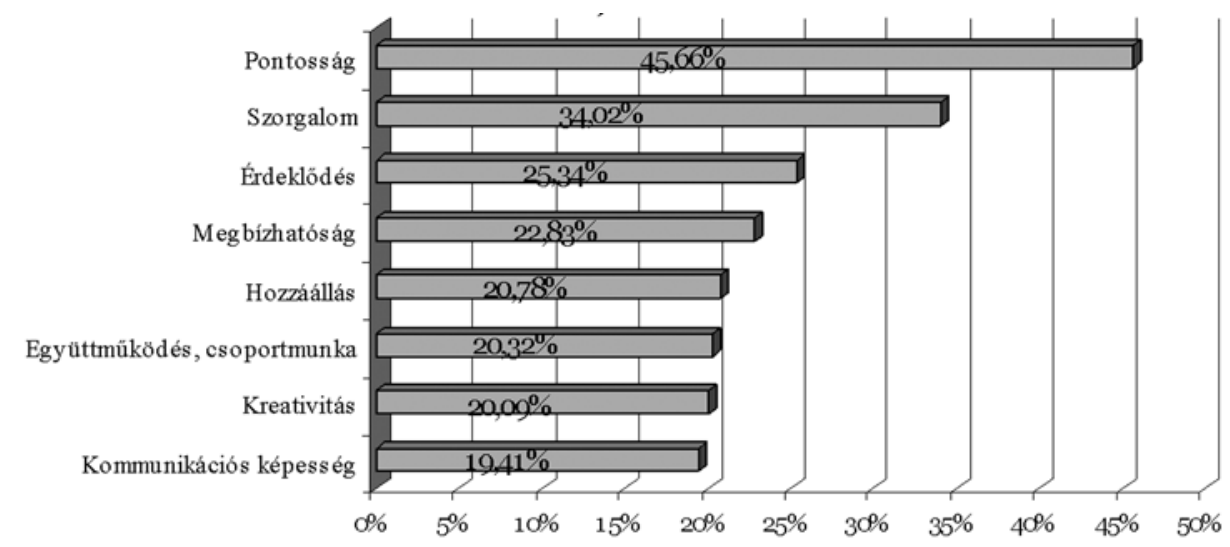

*A vállalatok három képességet nevezhettek meg.

Forrás: saját szerkesztés

Vállalati jellemzés a hallgatók munkájáról (említések aránya, \%, N=463)*

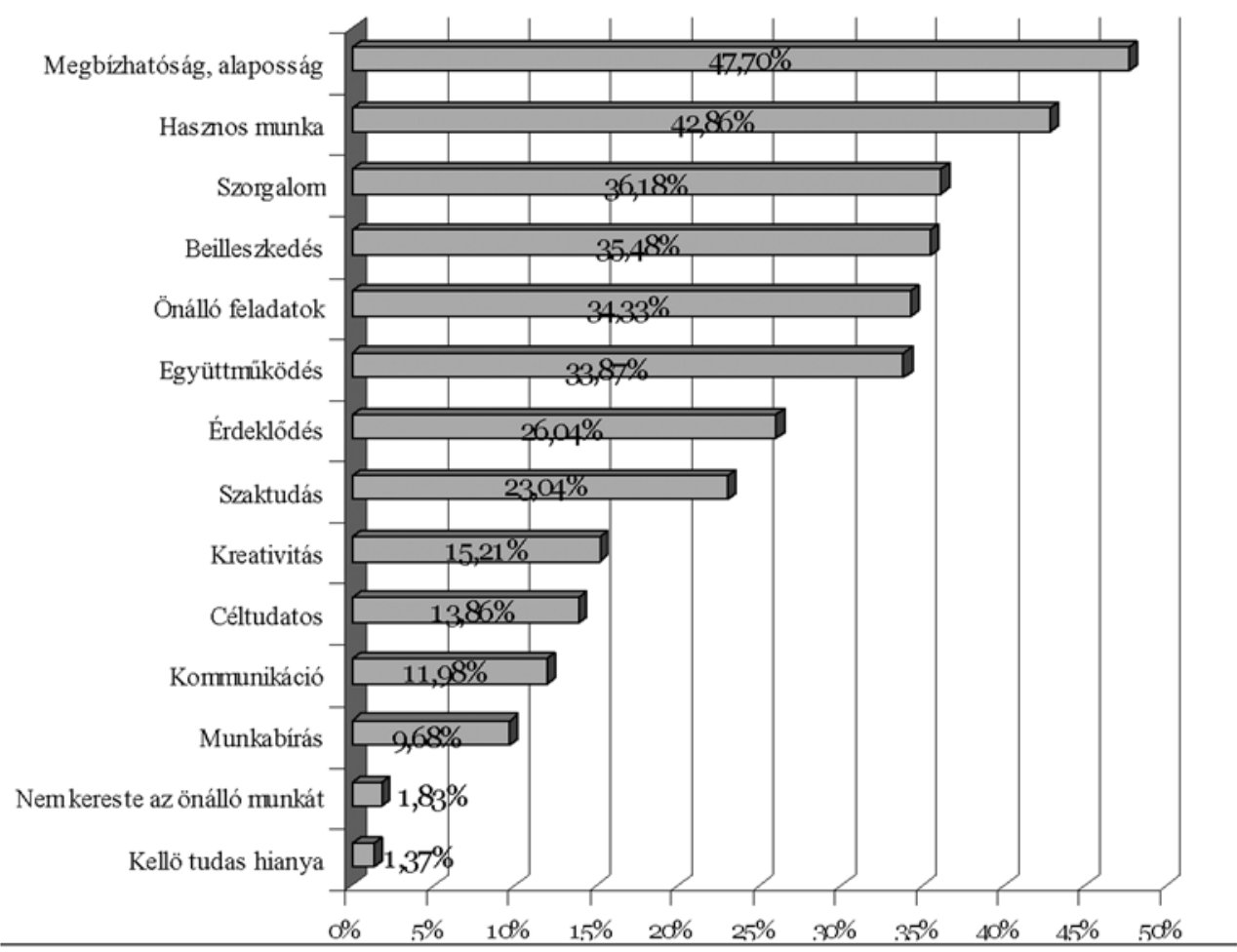

*Nem határoztuk meg, hány jellemzöt nevezhetnek meg a vállalatok.
A cégek visszajelzései egyértelmúen pozitívak, szerintük a hallgatók elsôsorban megbízhatóan végezték a feladatukat, és valóban hasznos munkát végeztek. Hozzávetólegesen azonos szinten áll a szorgalmas munkavégzés, beilleszkedés, az önálló feladatok és a jó együttmúködés. Negatív véleményt az esetek többségében egyáltalán nem fogalmaztak meg a vállalati válaszadók, inkább méltatták a gyakornokok munkáját.

A hallgatók értékelését is elvégezték a vállalatok az elôre megadott készségek mentén, amelyekról a hallgatók is elvégezték saját önértékelésüket. A két rangsor összehasonlítását a 12. ábra mutatja be a hallgatói értékelések alapján csökkenô sorrendben.

$\mathrm{Az}$ ábrából világosan látszik, hogy a hallgatók minden készség esetében alábecsülték magukat a vállalati értékelésekhez képest, ami megmutatja a hallgatók önképének viszonyulásáta külsőértékelő́k vélekedéséhez képest. A két fél által felállított rangsor, azaz a készségek sorrendisége hasonló. A legjobb értékelést a felelősségtudat, szorgalom és az alkalmazkodás kapta mind hallgatói, mind vállalati oldalról. 
Az empirikus kutatás keretei között nem tértünk ki arra, hogy milyen hatása lehet a vállalati méretnek a munkavállalókkal és diplomás pályakezdókkel szemben támasztott követelményekre, ezért ezt a szakirodalom alapján jellemezzük. A növekvô munkaadói elvárások ugyanis nem egységesek, hanem differenciáltak (Bencsik, 2008). A követelményeket vállalati méret szerint vizsgálva azt lehet megállapítani, hogy a kis- és középvállalkozásoknál elsôsorban a megbízhatóság, a problémamegoldó képesség és a szakmai tudás kerül előtérbe, mint elvárás. A kis- és középvállalatok másképp múködnek, mint a nagyvállalatok (például ritkábban fordul elô export), ezért esetükben az informatikai és nyelvismeretek háttérbe szorulnak.

Hallgatói és vállalati értékelés összehasonlítása ( $\mathrm{N}=463)^{*}$

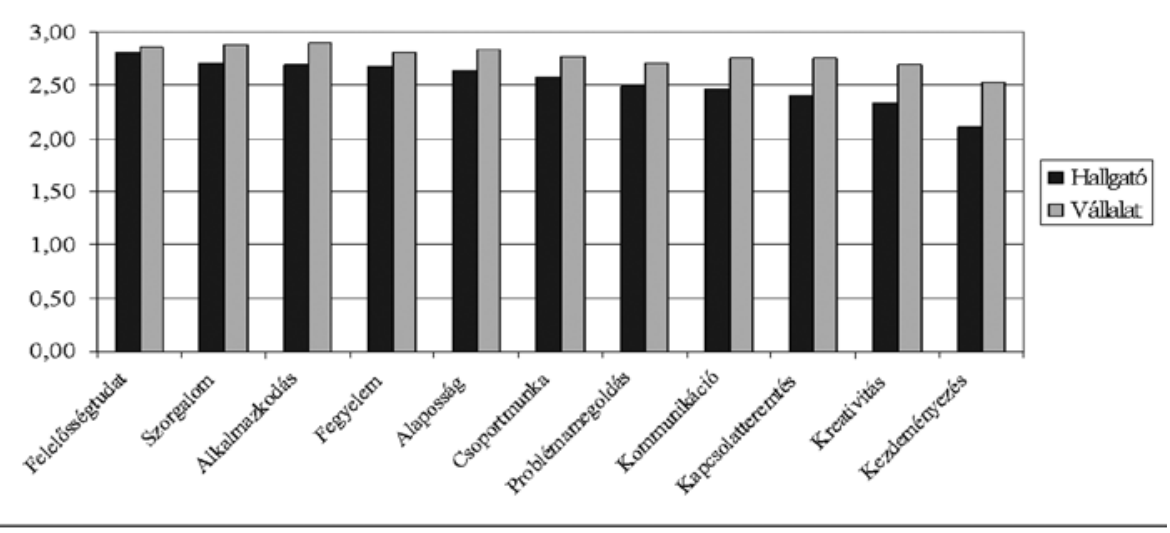

Magyarázat: 1-től 3-ig terjedő skála, ahol

$1=$ nem megfelelö

2 = megfelelö

3 = nagyon jó

*Elöre megadott készségeket értékeltek a hallgatók és a vállalatok. dását, készségeit, és ezt a pályakezdôk esetében tudják leginkább elérni, ók ugyanis még nem szocializálódtak egy adott vállalati kultúrához sem, vagyis könnyebben formálhatók a vállalat céljainak megfelelóen. A hazai vállalatok azonban nem kívánnak nagy energiát fordítani a képzésre, ók inkább a készen kapott, gyakorlattal rendelkező munkavállalókat preferálják (Tóthné, 2008) .Polónyi is egyetért ezzel, hiszen kutatásai alapján a külföldi tulajdonú vállalatok nagyobb preferenciákat adtak az együttmúködési készségnek (Polónyi, 2007). A hazai tulajdonú cégek esetében viszont az elméleti tudás gyakorlati alkalmazása a legfontosabb.

A munkaerópiac szereplói azonban nemcsak a hallgatók és a potenciális munkavállalók számára

12. ábra fogalmaznak meg elvárásokat, hanem közvetlenül az oktatás számára is lefektetik az általuk kijelölt követendő irányvonalat. Polónyi (2007) egyik kutatásában az elvárások mentén elemezte, hogy a munkaadók és a felsőoktatási intézmények kapcsolatát milyen jellemzókkel lehet leírni, és milyen feladatot fogalmaznak meg a cégek az egyetemek számára. A kutatás mintáját $99 \mathrm{db}$ szervezet alkotta. A minta nem reprezentatív, de megjelentek benne a versenyszféra vállalatai és a közszféra szervezetei is. Ez alapján a munkaadók a felsőoktatás legfontosabb feladatának tekintették az értelmiség képzését, a hosszú távú igényeknek

Forrás: saját szerkesztés
Az egyes gazdasági ágazatokhoz is hozzá lehet rendelni egy-egy kompetenciamixet (Csiszárik et al., 2009). Más képességek kerülnek előtérbe, ha valaki a mezőgazdaságban dolgozik, és szintén mások lesznek fontosak a pénzügyi-banki területen vagy az építóiparban. Ez is egy differenciálási lehetôség.

$\mathrm{Az}$ elvárások megkülönböztethetôk aszerint is, hogy a vállalat a versenyszférához vagy a közszférához tartozik. A versenyszférában olyan kompetenciák kerültek a rangsor élére, mint például a rugalmasság és az önálló munkavégzés, míg a közszférában a szervezőés irányítókészség szükséges a gyakorlati ismeretekkel kiegészítve (Polónyi, 2007). Megkülönböztethetjük a követelményeket attól függóen, hogy hazai vagy multinacionális cégról van szó. Utóbbi esetében jellemzóbb például, hogy preferálják a pályakezdóket, hiszen saját igényeik szerint kívánják formálni az alkalmazottak tu- megfelelő szakemberek képzését. Legkevésbé fontos feladatnak bizonyult a múveltség kialakítása és az idegennyelv-tudás fejlesztése. A munkáltatók úgy gondolják, hogy nagyon fontos az idegennyelv-ismeret, de annak fejlesztése nem a felsôoktatás feladata, hanem a közoktatásé. Az általános múveltség nyújtása a közszféra számára fontosabbnak bizonyult. A felsőoktatás feladatát egyértelmúen olyan szakmai tudásban jelölik meg a munkaadók, amely szoros kapcsolatban áll a gazdasággal, vagyis tovább építhetó, gyakorlatias tudást igényelnek. E tekintetben Polónyi (2007) nem talált különbséget a versenyszféra és a közszféra igényei között, tehát mindkét szféra elvárása a gyakorlatorientáció erôsítése. Az egyetemekrôl és a fơiskolákról kikerülő pályakezdók között pedig nem tesz különbséget a munkaadói szféra, ugyanazt várják el mindkét felsőoktatási intézmény diplomásaitól. 


\section{Összegzés}

Ezek alapján véleményünk szerint egyértelmú, hogy nemcsak a munkaerópiacnak érdeke az egyetemekkel és fóiskolákkal való kapcsolatfelvétel és kapcsolat megtartása, ápolása, hanem a felsőoktatási szféra számára is. A szakmai gyakorlati rendszerek, karrierirodák, pályakövetési rendszerek és egyéb kapcsolatorientációt magába foglaló megoldások fenntartása és múködtetése egyaránt szolgálja a munkaadók számára a tehetségek megtalálását, toborzási funkció teljesülését, a készségfejlesztést, az újszerú tudás áramlását és az oktatás számára a munkaeró-piaci visszacsatolást. A felsőoktatásnak nagy hasznot jelentenek a hallgatókról visszaérkező információk, hiszen ezeket beépítik az oktatási anyagba, úgy lehet alakítani a képzést, hogy az elvárásoknak leginkább megfelelő hallgatókat „neveljenek ki”, és ez a felsőoktatási rangsorokban is megmutatkozik (lásd különböző felsőoktatási rangsorok $^{8}$ ). Nemcsak a munkaadók ,vívnak harcot” egymással a legjobb munkavállalók megtalálásáért, hanem az oktatási intézmények között is tapasztalható egy igen komoly verseny a hallgatókért. Ezeket a potenciális hallgatókat akkor tudja magához vonzani a felsőoktatási intézmény, ha a többi intézményhez képest jó pozíciót foglal el, hírneve van, és jó imázzsal rendelkezik, kiváló szolgáltatást, gyakorlatorientált, versenyképes képzést nyújt, jó a kapcsolata az üzleti szférával, kiemelt szerepet kap a tehetséggondozás, végzősei hamar el tudnak helyezkedni, és összességében a felvételi rangsorok elôkelő helyezésével büszkélkedhet.

Az egyetemek (és a vállalati szervezetek) ismét átalakulások elốtt állnak, amelyet a turbulens változások, a globalizálódó gazdaság, a szervezetek hálózatosodása és az informatika mindent elsöprő fejlődése kényszerít ki. Ahhoz, hogy ezeknek a kihívásoknak egyetemünk, karunk meg tudjon felelni, szükség van a múködésében rejlő alapvető ellentmondások feloldására, tompítására. Milyen megoldási irányok állnak elóttünk? Most csak a BA kötelező szakmai gyakorlataihoz füződő szúk területére koncentrálva tettük meg megállapításainkat. A kötelező szakmai gyakorlatok tapasztalataiból kiolvasható, hogy mindhárom fél egyedi és kölcsönös előnyeinek (egyetem, hallgató, cég) biztosítása érdekében az alapok, értékek vizsgálata céljából szükség van reflexív, akár kritikai elméletalkotásra, az e területen folyó tudományos kutatások támogatására, a legjobb gyakorlatok számbavételén túlmutató kiterjesztésére és a tudományos eredmények gyakorlati szakemberekkel való megismertetésére, a céges tapasztalati eredmények oktatásba való integrálására. Feladatunk, hogy képesek legyünk megteremteni a nyílt kommunikáció és az ötletek cseréjének kultúráját, elősegíteni a közös gazdasági érdekek és az emberi törekvések összehangolásának embert próbáló munkáját.

\section{Lábjegyzet}

${ }^{1}$ A felsôoktatási intézmények és a munkaerópiac kapcsolatai alatt jelen tanulmányban azokat az interakciókat értjük, amelynek során a felsőoktatási intézmények és a munkaadók között annak érdekében jön létre együttmúködés, hogy az intézményból kikerülő hallgatók munkát kapjanak egy adott szervezetnél. Az együttmúködés célja a hallgatók gyakorlati ismereteinek bóvítése, gyakorlatszerzés, tapasztalatszerzés, kompetenciafejlesztés, vagy végleges elhelyezkedés.

2 ,Magyarországon az oktatás megtérülési rátája 1998-2004-ben a nóknél 0,106-ról 0,130-ra, a férfiaknál 0,118-ról 0,139-re emelkedett, a diplomások bérelőnye a nóknél 0,363-ról 0,594-re, a férfiaknál 0,550-ról 0,715-re nőtt a bértarifa-felvételek adataival becsült Mincer-féle alapegyenletek szerint." (Kertesi - Kollő, 2006: 203.)

${ }^{3}$ KSH: http://portal.ksh.hu/pls/ksh/docs/hun/xstadat/xstadat_eves/ i_wdsi001b.html (2010.05.30.)

${ }^{4}$ A kompetencia értelmezéséról lásd Henczi L. - Zöllei K. (2007): Kompetenciamenedzsment. Perfekt Gazdasági Tanácsadó, Oktató és Kiadó 17-19. o.

${ }^{5}$ Massachusetts Institute of Technology (az USA egyik leghíresebb magánegyeteme).

${ }^{6}$ A hazai felsőoktatás 2005-ös kutatási bevétele 21 milliárd forintot tett ki, ami az összbevétel 12\%-át jelenti (Polónyi, 2009).

779 észak-amerikai, egyesült királyságbeli és ausztráliai egyetemi kapcsolatokért felelős vállalati vezető megkérdezése alapján Lindsay arra az eredményre jutott, hogy az egyetemek és a vállalatok közötti oktatási együttmúködések egyik legfontosabb célja az, hogy biztosítsanak egy elismert, akkreditált egyetemi képzési programot a vállalati dolgozók számára, amely képes kiegészíteni a vállalat saját tanfolyamait. Továbbá ez utóbbiak megerősítésére és hitelességének növelésére is jó lehetôség az együttmúködés a vállalat és az egyetem között (Lindsay, 2009).

${ }^{8}$ Ezek közül a legismertebbek a következôk: HVG Felsôoktatási különszám 2009, Figyelő 2009-es melléklete a felsőoktatási rangsorokról, Heti Válasz Felsôoktatási Rangsor 2009.

\section{Felhasznált irodalom}

Barakonyi K. (2003): Felsőoktatási stratégiaalkotás. Harvard Businessmanager, 5. évf., 5. sz., 48-58. o.

Barakonyi K. (2004): Rendszerváltás a felsóoktatásban. Budapest: Akadémia Kiadó

Barakonyi K. (2009): A business schoolok szerepváltozásai. Vezetéstudomány, 40. évf., 1. sz., 2-15. o.

Bencsik A. et al. (2008): A kis- és középvállalatok tanulási-képzési gyakorlata a tudásalapúvá váló gazdaságban. Marketing \& Menedzsment, 42. évf., 5-6. sz., 42-50. o.

Benedek Sz. (2004): Diplomás pályakezdô munkanélküliek. Munkaügyi Szemle, 48. évf., 9. sz., 33-37. o.

Cappelli, P. (2008): Tehetségmenedzsment a 21. században. Harvard Business Review, 10. évf., 6. sz., 58-66. o. 
Csiszárik-Kocsir Á. et al. (2009): A kompetenciák mérése az emberi eróforrás-menedzsmentben és az oktatásban. Humánpolitikai Szemle, 20. évf., 7-8. sz., 132-140. o.

Dinya L. (2002): A „Bologna Folyamat” - A duális képzési rendszer szemszögéből. Magyar Felsőoktatás, 12. évf., 7. sz., 24-25. o.

Farkasné Kurucz Zs. - Lóránd B. (2007): Szakmai gyakorlatok és munkahálózatok a XXI. században. Nemzetközi konferencia, Miskolc: Miskolci Egyetem Gazdaságtudományi Kar, 284-291. o.

Farkasné Kurucz Zs. - Lóránd B. - Balogh G. (2008a): Methods to develop competitivness of the workforce. Professional experience and its systems. New Trends and Tendencies in Human Resource Management - East meets West: Nemzetközi konferencia. Pécs, 2008. június 13-14. Pécs: PTE KTK

Farkasné Kurucz Zs. - Lóránd B. - Balogh G. (2008b): A munkaerô versenyképességének elôsegítése a versenyképes környezetben. A szakmai gyakorlat rendszere és jellemzói. In: A gazdasági környezet és a vállalati stratégiák: Nemzetközi konferencia. Szeged, 2008. október 30-31. Szeged: MTA IX. Osztály Ipar- és Vállalatgazdasági Bizottság és SZTE GTK, 60-73. o.

Henczi L. - Zöllei K. (2007): Kompetenciamenedzsment. Perfekt Gazdasági Tanácsadó, Oktató és Kiadó 314. o.

Kabai I. - Szabó Sz. (2008): Pályakövetéses vizsgálat - felsôoktatás, munkaerôpiac. Budapest: Zsigmond Király Fôiskola http://www.zskf.hu/uploaded/akabai/20_ allasstart_2008_Kabai_Szabo_cikk.pdf (2009.10.20)

Kertesi G. - Köllő J. (2006): Felsőoktatási expanzió, „,diplomás munkanélküliség" és a diplomák piaci értéke. Közgazdasági Szemle 53. évf., 3. sz., 201-225. o.

Lindsay, R. (2009): Exploring the growing phenomenon of university-corporate education partnerships. Management Decision, Vol. 47, No. 8, 1313-1322. o.

Majó Z. (2000): A felsőoktatás és a munkaerópiac kapcsolata. Szeged, SZTE Gazdaságtudományi Kar Közleményei. JATEPress, Szeged 169-186. o.

Munkácsy F. (2004): A szakmai gyakorlatosok fogadása elősegíti a tervszerú munkaerô-utánpótlást. Munkaügyi Szemle, 48. évf., 1. sz., 3-17. o.
Nagy G. (2007): Egyetemek és öregdiákok kapcsolata Amerikában. HVG, 29. évf., 20. sz. 78-80. o.

Pálmai E. (2009): Diplomás-pályakövetés: ki mit tud. HVG, 31. évf., 31. sz., 53-55. o.

Polónyi I. (2007): A gazdaság és a felsőoktatás kapcsolatának néhány jellemzője - egy empirikus kutatás néhány megállapítása. Competitio, 6. évf., 2. sz., 149-177. o.

Polónyi I. (2009): A hazai felsőoktatás gazdasági múködése, szerveződése és vezetése a 2000-es évek legelején. Új Pedagógiai Szemle, 59. évf., 8-9. sz., 3-36. o.

Polónyi I. - Timár J. (2004): Munkaerôpiac és oktatáspolitika Magyarországon a rendszerváltás után. Közgazdasági Szemle, 51. évf., 11. sz., 1065-1072. o.

Selmeczy I. (2007): Diplomás pályakezdôk és egyetemi, főiskolai karok vállalati szemszögból. Munkaügyi Szemle, 51. évf., 11-12. sz., 46-49. o.

Slauhter, S. - Rhoades, G. (2004): Academic Capitalism and the New Economy. Baltimore, The Johns Hopkins University Press

Szabóné Mojzes A. (2008): Tömegesedés a felsőoktatásban. Pécs, Oktatás és Társadalom Neveléstudományi Doktori Iskola, Pécsi Tudományegyetem

Szalka É. - Czipf Cs. (2008): Az emberi tóke vállalati értékre gyakorolt hatása. Marketing \& Menedzsment, 42. évf., 5-6. sz., 4-14. o.

Tóth I. (2007): Diplomás pályakezdôk és egyetemi, főiskolai karok vállalati szemszögból - 2007. Budapest: MKIK Gazdaság- és Vállalkozáselemzô Intézet Kutatási Füzetek 1 . sz.

Tóthné Sikora G. (2008): Fókuszban a bolognai folyamat, az átalakuló felsőoktatás és a munkaerópiac. Munkaügyi Szemle, 52. évf., 4. sz., 7-10. o.

Vincze Sz. (2009): A diplomások túlképzésének megnyilvánulásai. Új Pedagógiai Szemle, 59. évf., 8-9. sz., 47-70. o.

Wright, $R$. (2008): How to Get the Most From University Relationships. MIT Sloan Management Review, Vol. 49, No. 3., 75-80. o.

Cikk beérkezett: 2010. 3. hó

Lektori vélemény alapján véglegesítve: 2010. 6. hó 